SDÜ ART-E

Güzel Sanatlar Fakültesi Sanat Dergisi

Haziran'21 Cilt:14 Sayı:27

ISSN 1308-2698

\title{
MITOLOJIK OLARAK SIMURG FIGÜRÜ VE FRANSA MILLI KÜTÜPHANEDE BULUNAN FIRAKNÂME ESERINDEKI TASVIRLERI
}

\author{
THE MYTHOLOGICAL SIMURG FIGURE AND ITS DESCRIPTIONS IN FIRAKNÂME IN THE \\ FRENCH NATIONAL LIBRARY
}

\author{
Sevda Emlak ${ }^{*}$
}

Öz

Hayvan üslubu erken devirlerden beri Türk sanatında mühim bir yere sahiptir. Üsluplaşmış hayvan figürü tasvirleri; özellikle el yazma eserlerin minyatürlerinde ve sayfa kenarlarındaki halkâr tezyinatında sıkça karşımıza çıkmaktadır. Hayvan figürleri içerisinde mitolojik özelliklere sahip olan Simurg kuşunun Fıraknâme eserindeki tasvirleri çalışmamızda incelenmiştir. Çalışmaya konu olan Fıraknâme Fransa Milli Kütüphanede Persan. 243 numara ile kayıtlıdır. Müstensih nüshası (1540-1560) olan eserin ilk nüshası (770H./1368-9)'de Salman Saveci tarafından Sultan Uveys için yazılmışır. Fırakname nüshanın tezyinatında bulunan Simurg figürlerinin mitleri ele alınmış ve kompozisyon içerisindeki tasvirleri belirlenmiştir. Çizimleri yapılan Simurg figürleri değerlendirilerek renk ve süsleme özellikleri ortaya konulmuştur.

Araştırmanın sonucunda, Simurg kuşu tasvirleri eserin alt ve üst cilt kabında, $1 \mathrm{~b}$ varağında $\mathrm{Hz}$. Süleyman Peygamberi konu alan minyatür sahnesinde, 10b, 13a, 20a, 29a varağındaki halkâr tezyinatında görülmüştür. Fıraknâme eserindeki Simurg tasvirinin simgesel özelliklerinin değerlendirilmesi sonucunda $1 b$ varağındaki minyatürde iyiliği sembolize eden bir figür olarak ele alınan Simurg, cilt kabında bir savaş sahnesinde güç simgesi olarak yer almıştır. Halkâr tezyinatında ise doğadan tasvir edilen ve sanatçının tasavvuru ile gelişen bir süsleme unsuru olarak kullanıldığı sonucuna varılmıştır.

Anahtar Kelimeler: Fıraknâme, Hayvan Tasviri, Simurg.

\section{Abstract}

Animal style has an important place in Turkish art since the early ages. Stylized depictions of animal figures are frequently encountered, especially in the miniatures of the manuscripts and the halkâr decoration on the sides of the page. The descriptions of the Simurg bird, which has mythological features among animal figures, in the work of Firaknâme have been examined in our study. Firakname, the subject of the study, is registered with Persan number 243 in the National Library of France. This work, which is a copy (1540-1560), was first written by Salman Saveci for Sultan Uveys on $770 \mathrm{H} . / 1368-9$. The myths of the Simurg figures found in the decoration of the Firakname manuscript were discussed and their depictions in the composition were determined. By evaluating the drawings of Simurg figures, their color and ornamentation features have been revealed.

As a result of the research, the Simurg bird depictions are found in the back and front cover of the binding of the work, in $1 \mathrm{~b}$ foil in the miniature scene about the Prophet Solomon, in the Halkâr decoration of foils 10b, 13a, 20a, 29a. As a result of the evaluation of the symbolic features of the Simurg depiction in the work of Firaknâme, Simurg, which was considered as a figure symbolizing the goodness

Araştırma Makalesi // Başvuru tarihi: 13.03.2021 - Kabul tarihi: 15.06.2021.

*Dr. Öğr. Üyesi, İzmir Demokrasi Üniversitesi, Güzel Sanatlar Fakültesi, Geleneksel Türk Sanatları Bölümü, sevda.emlak@idu.edu.tr, https://orcid.org/0000-0001-5311-6726. 
in miniature on $1 \mathrm{~b}$ foil, it took place as a symbol of power in a battle scene in the cover of the binding. It was concluded that in the halkâr decorations, it was used as an ornamentation element depicted from nature and developed with the imagination of the artist.

Key Words: Firaknâme, Animal Depiction, Simurg.

\section{Giriş}

Mitolojik hikâyelerde yer alan kuşlar her zaman olağanüstü efsanelerinden ötürü insanoğlu hafızasında önemli bir yer almaktadır. Geçmiş zamanlarda yaşamış veya zaten hiçbir zaman var olmamış mitolojik varlıklar üzerine çeşitli hikâyeler anlatılmaktadır. Bu efsanevi hayvanlar kültürlerin destan ve hikâyelerinde sıkça işlenmektedir. Simurg figürü de toplumdan topluma farklı şekilde adlandırılarak çeşitli efsaneler ile dile gelmiştir.

Simurg figürü yazma eser tasvirlerinde sıkça işlenmiş ve betimlemelerine yer verilmiştir. Yazma eserlerde bitkisel motiflerin yanı sıra üsluplaşmış hayvan figürleri minyatür tasvirlerinin yanı sıra halkâr tezyinatında da kullanılmıştır. Çeşitli konularda işlenen ve özellikle edebi eserlerde rastladığımız hayvan üslûbunun işlendiği eserlerden biri de Fransa Milli Kütüphanesinde bulunan müellifi Selman Saveci, müstensihi Malik el- Daylami olan Fıraknâme (Persan 243 env.) eseridir.

Fıraknâmeler; genel anlamda ayrılık konularının işlendiği edebi eserlerdir. Bu eserlerde sevgiliden ayrı kalıp, uzak düşmenin yanı sıra eş, çocuk, kardeş ve arkadaş gibi sevilen birinin ölümünün üzerine çekilen hicran ve hasret konularını işlemektedir (Yaylalı, 2016:203-219). Fırâknameler Fars edebiyatında ayrılığı ve özellikle sevgiliden ayrı kalmayı konu edinmiştir. Genel olarak mesnevî nazım şekliyle, bazen de mensur biçimde yazılmıştır. Bu eserlerde uzaktaki sevgilinin vefasızlığından, bahttan, yaşlılıktan ve zamandan gelen üzüntüler dile getirilir (Ziyâyî, 1376-1378:1027-1028, Tavukçu, 2004:89-122). Ayrılığı anlatan Fıraknâme'ler; Fırâk, Fıraknâme, Fürkâtnüma, Fürkatnâme, Firâkiyye, Gurbetnâme, Hecrnâme ve Hicretnâme gibi isimlerle yazılmış eserlerdir (Tavukçu, 2004:90).

Illk Fırâkname örneğini Enveri'nindir (ö. 583/1187). Kaynaklar Hâcû-yı Kirmânî’nin de (ö. 753/1352-1353) mesnevî nazım şekliyle bir eserinin olduğunu yazmaktadır. Ancak Klâsik Fars 
Edebiyatında bu tarzın en önemli temsilcisi Selman Saveci gösterilmektedir (Tavukçu, 2004:89122). Emir Hüsrev-i Dihlevi, Selman Saveci, Zuhûri-yi Turflizi, Mehcûr gibi şairler de İran Edebiyatının Fıraknâme yazarlarındandır. Bu alanda yazılan eserler, daha çok beşerî hassasiyetleri dile getirmektedir (Tavukçu, 2007:197-220).

Çeşitli kütüphanelerde çok sayıda yazma nüshası bulunan Selmân'ın şiirleri ilk defa Külliyyât adı altında taş baskıyla neşredilmiş (Bombay 1890) (Karaismailoğlu, 2009:446-447). Türkiye'de Süleymaniye Ktp. Hâlet Efendi, 356; İstanbul Ü. Ktp. FY., 131; İstanbul Ü. Ktp. FY., 442 (306b-332b yk.); Nuruosmaniye Ktp., 4188, 4189, 4190 gibi yazma eser kütüphanelerinde nüshaları bulunmaktadır. Bu nüshalar Abbas Ali Vefai tarafından külliyat içerisinde neşredilmiştir (Tavukçu, 2007:197-220). Saveci'nin Fıraknamesi üzerine Davut Ali Katnik tarafından yüksek lisans tezi yazılmıştır (1993, AÜ Sosyal Bilimler Enstitüsü). Fars edebiyatında birçok örneğine rastlanılan iki kahramanlı aşk mesnevilerinin Türk edebiyatında birçok örneği bulunmaktadır (Tavukçu, 2004:89-122). Türk ve Fars edebiyatındaki Fırâknameler üzerine Orhan Kemal Tavukçu çalışmalar yapmıştır.

Fars edebiyatının önemli eserlerinden olan Fırâkname'nin müstensih nüshası 724 beyitten oluşmaktadır. Eser Sultan Üveys'in çok sevdiği dostlarından biri olan Bayram-Şah'ın Gilan savaşına katılması ve bu savaşta ölmesi üzerine sultanın sevdiği dostunun ölümü karşısında duyduğu acıları anlatmak için Selman Saveci'ye yazdırılmıştır (m. 778H./1376) (Emini, 1998:71-91). Eserde şair metinlerinde birçok tasvire yer vermiş ve betimlerinde edebî sanatlara başvurduğu görülmüştür. Şair dört mevsimin gelişini ve onların tabiatta oluşturduğu değişiklikleri ve güzellikleri farklı benzetmeler aracılığıyla etkileyici bir şekilde ele almıştır (Yaylalı, 2016:203-219).

Yazma eserlerde metnin ihtiva ettiği bilgilerin yanı sıra tezyinatın büyük önem taşıdığı aşikârdır. Yapılan tezyinat eserin yazıldığı yüzyıın sanat anlayışı hakkında bilgi vermektedir. Bu eserlerde kimi zaman metnin muhteviyatına ilişkin bir tezyinat yapılırken kimi zamanda bağımsız yapıldığı görülmektedir. Yapılan bezemeye yönelik çeşitli motifler kullanılmaktadır. Bu motifler arasında tezyinatta kullanılan hayvan figürleri çoğu zaman metaforik anlamları ile kullanılmaktadır. Hayvan figürleri yazma eserlerde minyatür tasvirlerinin yanı sıra cilt ve halkâr 
tezyinatında da kullanılmaktadır. Üsluplaştırılmış hayvan figürleri özellikle İran (bilhassa Safevi dönemi) halkâri örneklerinde yer almaktadır (Derman, 1997:365-367).

Hayvan figürleri arasında efsanevi bir kuş olan Simurg figürü; Arap mitolojisinde Anka, İran mitolojisinde Simurg, Türk mitolojisinde Zümrüdüanka veya Simurg (Simurg u Anka) olarak isimlendirilmektedir (Erdem, 1991:198-200). Farsça'da “otuz kuş" anlamına gelmektedir (Eliade, 2001:42). Ön Asya efsanelerinde Simurg, çoğu kaynaktan incelendiğinde Batı'da eski Mısır kökenli "Phoenix" ve İslami çevrelerde "Hüma" devlet kuşundan tamamen farklıdır. Hint mitolojisinde "Garuda", Altay mitolojisinde ise çift başlı kartaldan kısmen farklı özellikler taşıyan bir kuştur (Erdem, 1991:198-200). İran mitolojisinde geçen ve Gaokerena ağacı tepesindeki "Saena" kuşu sonraları "Simurg" ve "Senmurw" (Hınnels, 1985:22) olarak anılmıştır. Bu kuş bazı karakterleri açısından öteki kuşlarla benzerlikler taşımaktadır. İran tesiri ile Türk mitolojisinde yer alan bir figürdür. İslamiyet'ten sonra hususiyetle tasavvufla ilgili mitsel niteliklerin hissedildiği hikayeler içerisinde karşımıza çıkmaktadır (Çoruhlu, 2002:132).

Simurg figürü tasvirlerde kartal başlı, pençeli, geniş kanatları olan, kuyruk bölgesinde uzunca kıvrımlar bulunan, sakallı ve ibikli olarak resmedilmiştir (Çoruhlu, 2014:23). Büyük ve çok iri şekilde tasvir edilen Simurg bin bir gece masallarında gökyüzüne yaklaştığında yağmur bulutu gibi havayı kararttığı ve iki yavrusunun da kanatlarını açtığında büyük bir gölge meydana getirdiği bilinmektedir. Simurg'un kanatlarını açtığında güneş ışığını engelleyerek bir ülkeyi karanlıklar içerisinde bıraktığı gibi pençeleriyle pars ve filleri kaldırabildiği anlatılmaktadır (Duymaz, 1998:91-97).

Şahnâme, Avesta ve Pehlevice gibi metinlerde, Simurg figürü şaşırtıcı ve olağanüstü özellikleri olan bir varlık olarak gösterilmiştir. Heybetli kanatları, gövdesinin iki tarafında renk cümbüşü yaratan dört kanatlı, bir kartalın gagası gibi kalın gagası olan ve yüzü insan yüzüne benzeyen bir kuş şekliyle yorumlanan bu kuş kuşların efendisi anlamına gelen "şahi-murgan" olarak geçtiği de bilinmekle beraber yazma eserlerde tasvirlerine sıkça rastlanmaktadır (Mehran, 2017:161-162).

Simurg ile ilgili diğer bir metaforik söylence de bu kuşun Kafdağı'nın tepesinde bulunan sandal, öd ve abanoz ağacından oluşan köşke benzer bir yuvasının olduğudur. İnsanlar gibi 


\section{SDÜ ART-E}

Güzel Sanatlar Fakültesi Sanat Dergisi

Haziran'21 Cilt:14 Sayı:27

ISSN 1308-2698

düşünüp konuşabilen bu kuş çok parlak olduğundan bakanın gözlerini kamaştırmaktadır. Tüylerinin sürüldüğü yaralar iyileşir ve Kafdağı'nı aşmak içinde ona binmek gereklidir. Çok yükseklerden uçmak ve havada uzun süre kalabilmek Simurg'un en belirgin özelliğidir (And, 2008:321). Simurg figürünün Şehnamede geçen kutsi vasıflarının yanı sıra tüm kainattaki gizliliklerden haberi olan, güçlükleri yenebilen, geleceği sezen bir kabiliyete haiz olduğu kabul edilmektedir (Yıldırım 2013:152).

Simurg figürünü işaret eden, daha doğrusu bu efsanevi kuşun ikonografisini ve onunla alakalı tasavvurları çağrıştıran birçok tasvir mevcuttur. Tasvirlerde iyiliği sembolize eden Simurg figürleri bulunmaktadır. Yazma eserler üzerinden simurg figürüne dair betimlemelere baktığımızda Firdevsi'nin Şehname eserinde Zal'i yuvasında besleyip büyütmesi (TSM H. 1480), (And, 2008:321) sahnesi iyiliği simgelemektedir. Falname eserinde (TSM.H.1703) Bukrat'ın (Hipokrat) Simurg'a binip ilaç almak için Kafdağı'na gitmesi, yine Hz. Hamza'nın Simurg üzerinde Kafdağı'na uçması (TSM H. 2134) (And, 2008:322) iyilik simgelerindeki manalarını ortaya koymaktadır. Binbir gece masallarında da şehzade Elmas, Kafdağı'nın ortasında bulunan Vakak şehrine gitmek için Simurg'un üzerinde okyanusu aşmaktadır (Duymaz, 1998:91-97). Türk masallarında da Zümrüdüanka adıyla rastlanan Simurg'un sütünün şifalı olduğu ve bu sütten içen kişinin sağlığına kavuştuğu belirtilmektedir (Bilgehan, 2003:14-7). Simurg figürünün işlendiği ve iyi vasıflı söylenceleri destekleyecek başka minyatür tasvirleri de bulunmaktadır.

Efsanelerdeki bu koruyucu ve iyilikler yapan Simurg'un bir de kötü kalpli, canavar niteliğinde olanı bulunmaktadır. Bu kötü özellikli Simurg ise yüksekçe bir dağın tepesinde yaşar ve büyüklük olarak "uçan bir dağ"ı veyahut "siyah bir bulut"u andırmaktadır. Her bir yavrusu kendi büyüklüğünde olan kötü vasıflı Simurg'un yavrularıyla birlikte uçtukları zaman çok büyük bir gölge meydana getirdiği bilinmektedir (Erdem, 1991:198-200).

Kötü vasıflı Simurg'u çağrıştıran tasavvurlara bakıldığında Şehnâme eserinde İranlı İsfendiyar, Yedi Menzili geçerken beşinci menzilde, dağın doruk noktalarında bir Simurg ile karşılaşır ve bu kuş İsfendiyar'a saldırır. Bu kötü vasıflı Simurg, önceden bu duruma hazırlıklı olan İsfendiyar tarafından öldürülür. Minyatür (Topkapı Sarayı Müzesi, Hazine 1512, varak 409) sahnesindeki şeytani vasıflı Simurg kutsi ve iyilik yönleri olan Simurg figüründen ayrı kötü nitelikleri olan bir kuştur. Dolayısıyla İsfendiyar'ın Dağ’da karşılaştığı Simurg, ejderha kuşu gibi 
kutsi bir özelliğe sahip olmaması hasebiyle İsfendiyar tarafından öldürülüyor (Purnamdariyan, 1955:32, Dieji, 2007:121).

Simurg (Kuş) imgesi, tasavvufta ruh ile ilişkilendirildiğinde kuşların Kafdağı'na yaptıkları yolculuğun gerçekte ruhun özüne yaptıkları yolculuk şeklinde yorumlanır. Söylemde mevzusu geçen kuşun, kül, ateş, ağaç, ayna, yol ve dağ gibi metaforik tasavvurlar ile Tanrı'ya ulaşma yolunda bilge insana dönüşme araçlarını ifade eder. Kâmil insanda Simurg gibi bilgelikle ilişkilendirilmiştir (Karakuş, 2020:73). Kafdağı'nda yaşayan, yükseklerden uçan ve kolayca avlanamayan Simurg'un bu özellikleri sebebi ile erişilmesi çoğu zorlu durumları ifade etmek amacı ile kullanılmıştır (Pala, 1991:201). İslam mitinde, Simurg kuşların şahı olarak bilinir. Hz. Musa devrinde ortaya çıkmış, Hicaz'a gitmiş, Hz. Süleyman'ın meclisinde bulunmuştur. Kısas-ı Enbiyalarda Hz. Süleyman'la ilgili kısımlarda "Anka Kuşunun Öyküsü" adlı kıssa da Simurg ile Hz. Süleyman arasında geçen olaylar anlatılmaktadır. Diğer taraftan rivayetlere göre $\mathrm{Hz}$. Zülkarneyn, Simurg ile Kafdağı'nda görüşmüşlerdir (Batislam, 2002:185-208).

Simurg figürünün yok olmasına ilişkin söylencelerde ise Peygamberler kesiminde $\mathrm{Hz}$. Hanzale bin Safvan ile ilgili bölümde Hz. Hanzale (İslâm'dan önce tevhit inancına bağlı kaldığı veya Ashâbü'r-res'e peygamber olarak gönderildiği rivayet edilen kişi) (Çağrıcı, 1997:53) insanların canına kasteden Simurg'un nasıl yok olduğuna dair hikâye iki minyatürle anlatılmaktadır. Bu kıssayı gerek Demiri'de, gerek Nüzhetûl-Kulûb’ta görmekteyiz. Demiri, "zamanın peygamberi" şeklinde yorumlayarak Peygamber'in adını vermeden öyküden kısaca söz etmiştir. Bir düğünde Simurg damat adayını havaya kaldırmıştır, bu sebeple Peygamberin duası ile Allah onu insanların arasından alarak okyanusa atmıştır. Böylece bu efsanevi kuş sadece adının var olduğu ancak kendinin yok olduğu bir hayvan olarak kalmıştır. Nüzhetû'lKulûb'e göre de Simurg, Peygamber Hz. İsa ile Hz. Muhammed (SA.V.) arasında bir dönemde yaşamıştır. Simurg bir gelini mücevher ve giysileri ile havaya kaldırmış, Hz. Hanzale ise Tanrıya yakarmış, Tanrı da Simurg'a ateş yollamış ve Simurg yok olmuştur (And, 2008:321). Peygamberimiz Hz. Muhammed'den (S.A.V.) önce bir peygamber bedduasıyla yok olan Simurg (Batislam, 2002:185-208) figürü ile ilgili bir başka bilgiye göre, bu kuş yedi yüz yıl yaşamaktadır. Ancak öleceğini anladığında ise kendini yakarak yok edip sonra küllerinden tekrar doğduğu efsaneler arasında yer almaktadır. Böyle söylemlerde Simurg, yanarak yenilenmenin, yeniden 
doğuşun, değişimin, ölümlü varlığın ölümsüz varlığa dönüşümünün simgesi olmuştur (Güler, 2014:63-72).

Kitap sanatlarında önemli bir yer tutan hayvan tasvirleri; Türk sanatının da önemli bir halkasını oluşturmaktadır. "Hayvan Üslubu" adı verilen vahşi hayvanların ve mitolojik yaratıkların mücadelelerini tasvir eden Orta Asya'ya özgü (Begiç, 2017:26) birçok eser bulunmaktadır. Mimari, tekstil, çini vb. birçok alanda yer alan hayvan üslubunun çeşitli yazma eserlerde ele alındığı görülmektedir. Bu hayvan tasvirleri arasında aslan, kaplan, pars, dağ keçisi, geyik, kartal gibi vahşi hayvanlar ile simurg ve grifon gibi efsanevi hayvanların resimleri ya da birbirleri ile mücadele sahnelerinin (Begiç, 2017:26) birçok alanda yer aldığı gözlemlenmiştir.

\section{Yöntem}

Araştırmanın modeli, evren ve örneklem, verilerin toplanması, analizi ve değerlendirilmesi ayrıca metotları hakkındaki bilgiler yöntemimizi oluşturmaktadır.

\section{Araştırma Modeli/Deseni}

$\mathrm{Bu}$ araştırma ile var olan durumun var olduğu haliyle betimlenmesi amaçlandığından araştırma betimsel tarama modelinde bir araştırmadır (Karasar, 2008:77) Araştırmanın verileri Fransa Milli Kütüphanesi'nin, İslam koleksiyonu dijital veri tabanından elde edilmiştir. Araştırmada Fıraknâme'deki simurg figürlerinin mitlerine yer verilerek, kompozisyon içerisindeki tasvirleri belirlenmiştir.

Yazma nüshanın genel ihtivası ve Fıraknâmeler ile ilgili bilgilere yer verildikten sonra eserin görselleri üzerinden tezyinat özellikleri değerlendirilmiştir. Eserdeki Simurg figürleri tek tek tespit edilerek kompozisyon özellikleri belirlenmiştir. Tezyinatta kullanılan renkler, sayfa düzeni içerisinde figürün hangi motifler ile tasvir edildiği tespit edilmiş, kompozisyon bütünlüğü ile ilgili bilgilere yer verilmiştir. Simurg figürünün çizimlerine yer verilmiş bu figüre atfedilen mitler üzerinden değerlendirme yapılarak sonuca varılmıştır. Değerlendirme sonucunda Fıraknâme eserindeki Simurg figürlerinin, nüshadaki kullanım alanına ilişkin bilgiler ortaya konulmuştur. 


\section{Evren ve Örneklem}

$\mathrm{Bu}$ araştırmanın evreni, Fransa Milli Kütüphanesinde bulunan Fıraknâme eseri oluşturmaktadır. Araştırmada evrenin tamamına ulaşılmıştır.

\section{Veri Toplama Araçları}

Bu araştırma genel tarama modeli olarak yapılmıştır. Çalışmaya Fransa Milli Kütüphanesinin İslam koleksiyonu veri tabanından yazmalar incelenerek başlanmıştır. Yazma nüshalar arasından Fıraknâme eseri çalışma konusu olarak belirlenmiş ve konu ile ilgili bilimsel veriler taranmıştır. Belirlenen Fıraknâme isimli eserdeki Simurg figürleri makale kapsamında incelenmeye başlanmıştır. Yazma nüshadaki Simurg figürü ele alınarak, çizimleri yapılmış, renk ve kompozisyon özellikleri değerlendirilerek incelenen eserindeki Simurg figürü mitlerine ve tezyinatına dair bilgi verilmiştir.

\section{Bulgular}

Selmân-ı Sâvecî’nin Müellifi olduğu Fırakname edebiyatta farklı dönemlerde birçok şaire esin kaynağı olmuştur. Salmân Sâvecî́nin Fıraknâmesinin ilk nüshası 770 H./ 1368-9 M. tarihinde Farsça yazıımış bir mesnevidir.

Çalışma konumuz Fransa Milli Kütüphanesinde PERSAN.243 envanter numarası ile kayıtlı olan 1540-1560 (Şairin yaşadığı yüzyıl ile ilişkilendirilerek tarihlendirilmiştir) dolaylarında yazılan Fıraknâme nüshasıdır. Müstensihi Malik el- Daylami olan eser Lirik şiir şeklinde yazılmış ve 724 beyit şiirden oluşmaktadır. Farsça, Nestalîk hat yazı çeşidi ile sayfa başına 13 satır, iki sütun halinde yazılmıştır. Eser Reims baş piskoposu Marurice Le Tellier tarafından Kraliyet Kütüphanesine bağışlanmıştır. Yazma nüsha günümüzde Fransa Milli Kütüphanesi envanter kayıtlarında yer almaktadır (https://archivesetmanuscrits.bnf.fr/ark:/12148/cc101451q).

Yazma nüshanın cildi sağlam durumdadır. Cildinin iki kabı bulunmaktadır. Cildin hem iç hem dış kabında tezyinata yer verilmiş. Eserin 1b, 2a varağına minyatür tasviri, 2b'de klasik üslupta başlık tezhibi 3b, 4a, 5a, 6a, 6b, 7a, 12b, 13b, 14b, 16a, 17b, 18a, 19b, 20b, 23a, 25b, 26a, 27a, 28a, 29a, 29b, 30a, 31a varağında ara başlık tezhipleri, 1b ve 32a varak aralığında ise halkâr, 32a varağında ise ketebe kaydı tezyinatı bulunmaktadır. Mail yazı yazıımış bazı 
varaklarda muska tezhibi ve satır arası tezhibi bulunmaktadır. Eserin 1a, 1b, 2a, 2b, 4a, 4b, 6a, 6b,7a, 7b, 9a, 9b, 10a, 10b, 11a, 11b, 12a, 12b, 14a, 14b, 15a, 15b, 16a, 16b, 17a, 17b, 18a, 18b, 19a, 19b, 20a, 20b, 21a, 21b, 22a, 22b, 23a, 23b 25a, 25b, 26a, 26b, 27a, 27b, 28a, 28b, 29a, 29b, 30a, 30b, 31a, 31b varağı nohudî renk, 3a,3b, 5a, 5b, 8a, 8b, 13a,13b, 24a, 24b, 32a, 32b somon rengindedir.

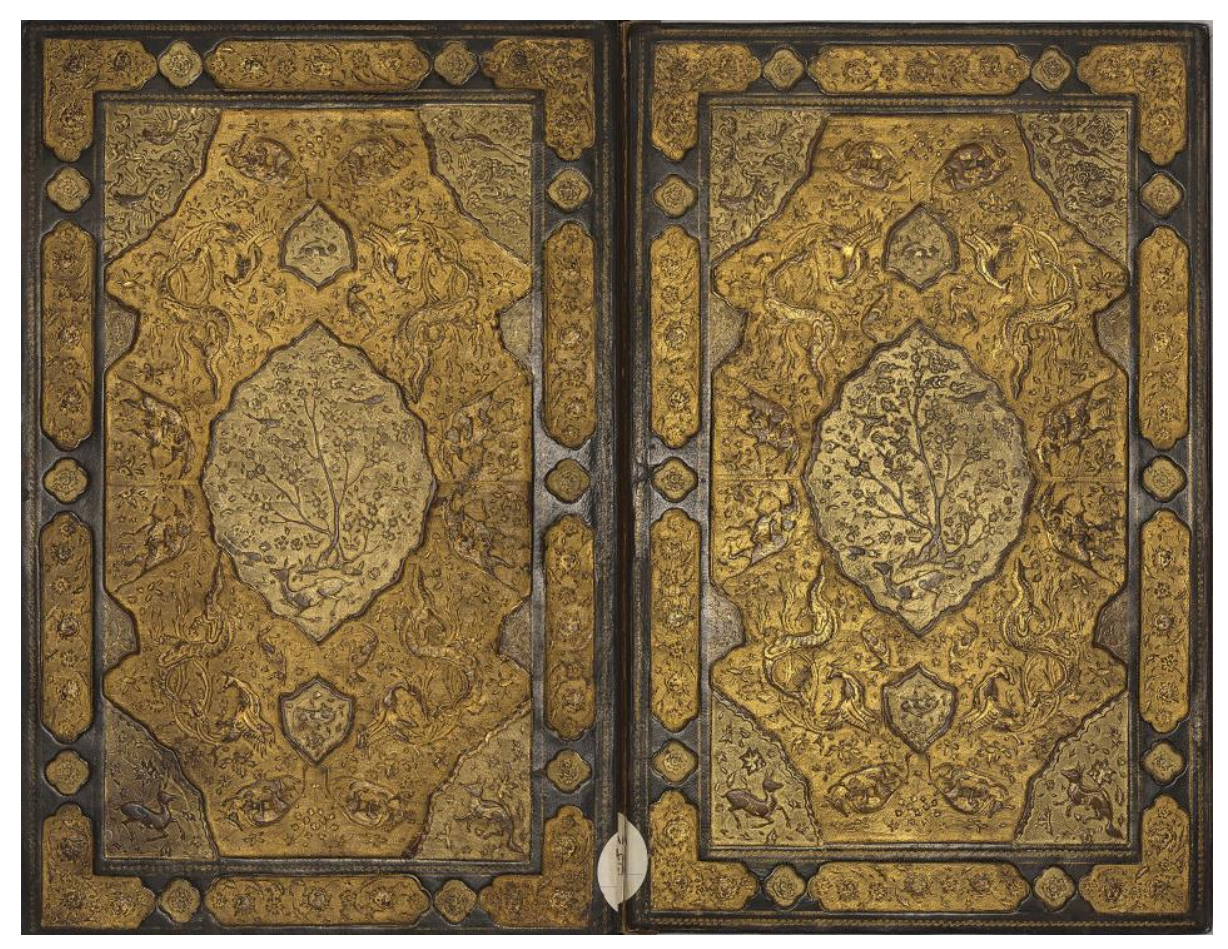

Görsel 1. Fıraknâme, Ön ve Arka Cild Kabı, Fransa Milli Kütüphanesi, İslam Koleksiyonu, $205 \times 313$ mm. https://gallica.bnf.fr/ark:/12148/btv1b6001244v/f1.item.r=simurg.

Eser kahverengi deri ile kaplı mülemma cilttir. Tüm yüzeyi altın ile kaplı olan cildin alt ve üst kabında şemse, salbek, köşebent ve dış pervazdan oluşan bir kompozisyon yapılmıştır. Şemse oval ve dendanlıdır. Şemse içine bahar dalı ağacı yerleştirilmiştir. Ağacın yanında çok zarif bir şekilde oturan ceylan figürü yer almaktadır. Aynı zamanda ağaç üzerinde kuşlar tasvir edilmiştir. Köşebent ve şemse arasında kalan zeminde ise hayvan figürleri ve bitki motifleri kullanılmıştır. 1/4 simetrik oranda yapılan kompozisyonda üç gruptan oluşan hayvanların dövüş sahnelerine yer verilmiştir. Bu sahnelerden biri Ejderha ve Simurg dövüş tasviridir. Ejderha ve Simurg dışında iki ayrı dövüş sahnesi daha yer almaktadır. Ancak bu sahnelerdeki hayvan figürleri birbiri üzerinde tasvir edildiğinden hangi figürler olduğu tespit edilememiştir. Ancak 
figürlerin kuyruk ve baş tasvirlerinden tilki, pars olabileceği düşünülmektedir. Dövüş sahnelerinin dışında ejderha ve simurg figürünün yanında oturur şekilde bir tilki figürü yer almaktadır. Bitkilerden ise penç, goncagül ve yer bitkileri tasvirleri görülmektedir. Dört tarafa yapılan köşebentlerde ise farklı hayvan figürleri ile bitki motiflerine yer verilmiştir. Sağ alt köşebentte tilki figürü, sol alt köşebentte ceylan figürü, bitkisel motiflerden ise yaprak, hatai ve goncagül gibi uslûplaştırılmış motifler yer almıştır. Sağ üst köşebentte leylek, kuş figürü, sol üst köşebentte ise uçar şekilde tasvir edilen iki kaz figürü ve bulut motifi tasvirleri görülmektedir. Cilt tezyinatında şemse ve köşebentleri çerçeveleyecek şekilde dış pervaz yapılmıştır. Dış pervaz paftalara ayrılmış içleri hatayi gurubu motifleri ile tezyin edilmiştir. Salbeklerin içinde tam stilize bitkilerden hatai, yaprak motiflerine, hayvanlardan ise tavşan figürüne yer verilmiştir. Cildin alt ve üst kabındaki tezyinat aynıdır. Ciltteki motiflerde bozulma bulunmamakla beraber derisi iyi durumdadır. Eserin dış kabının dışında bir de iç kabı bulunmaktadır. İç kabında, dış kabında rastladığımız hayvan figürlerine yer verilmeden deri üzerine rumi motifleri ile renkli bir tezyinat yapılmıştır. 
SDÜ ART-E

Güzel Sanatlar Fakültesi Sanat Dergisi

Haziran'21 Cilt:14 Sayı:27

ISSN 1308-2698

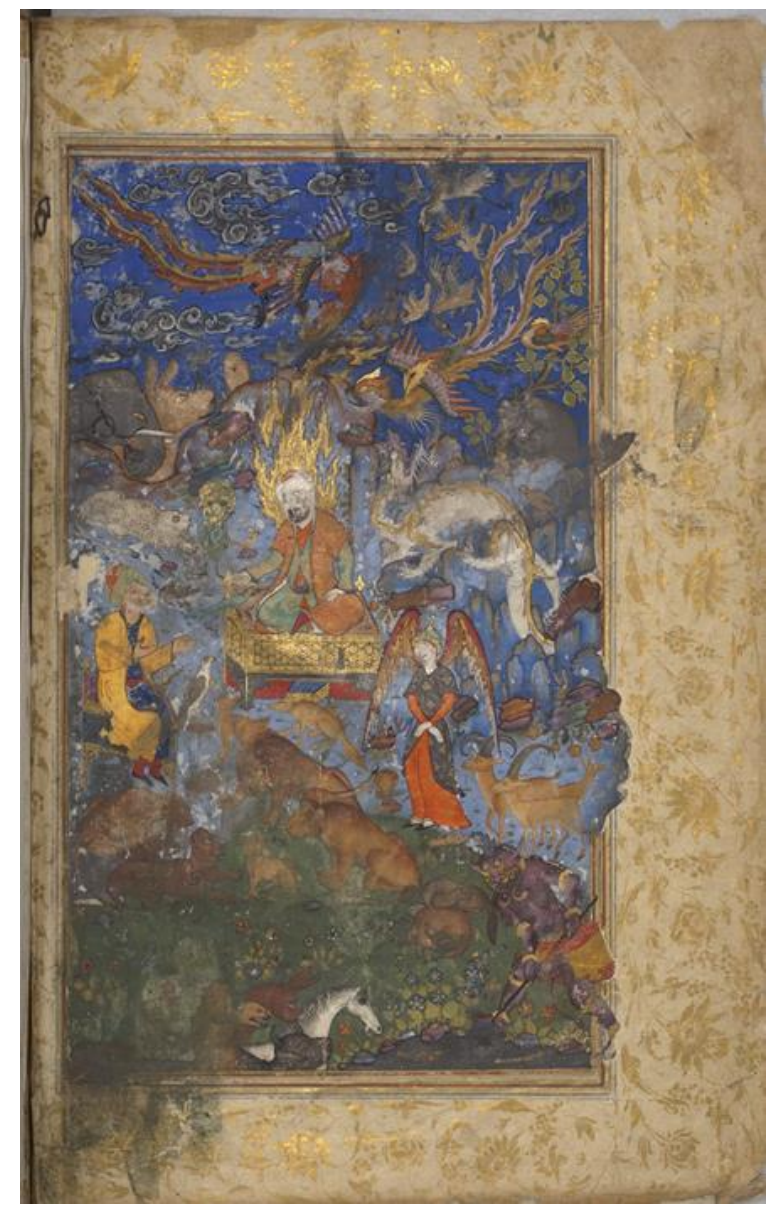

Görsel 2. Fıraknâme, Varak 2a Hz. Süleyman Peygamber, Fransa Milli Kütüphanesi, İslam koleksiyonu, (148×238mm.) https://gallica.bnf.fr/ark:/12148/btv1b6001244v/f6.item.r=simur.

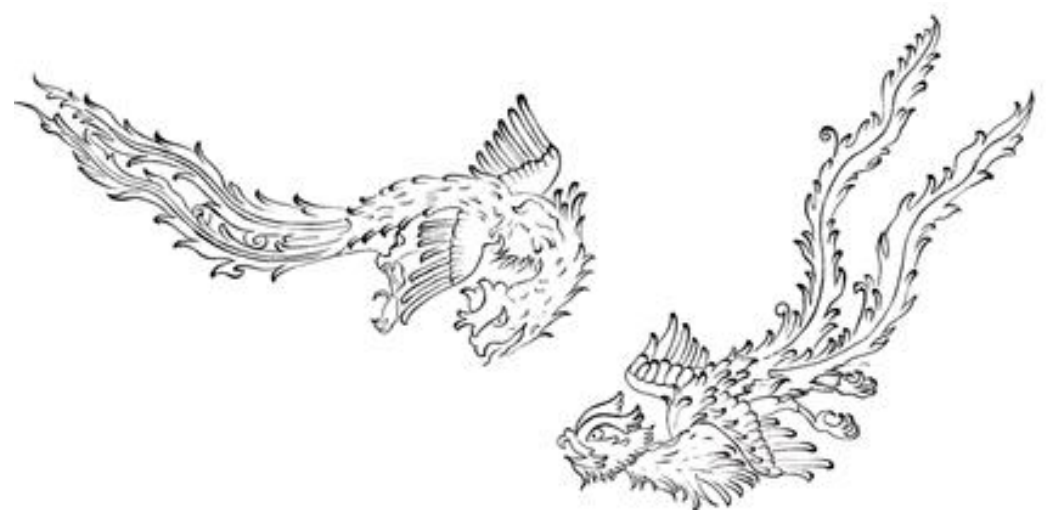

Çizim 1. Emlak, 2021, Varak 2a, Hz. Süleyman Peygamber Konulu Minyatür Sahnesi Simurg Figürü. 
Eserin 2a varağında yer alan minyatür Süleyman Peygamberi konu almaktadır. Altın ile renklendirilen tahtta oturmuş bir şekilde resmedilen $\mathrm{Hz}$. Süleyman'ın etrafında çeşitli hayvanlar tasvir edilmiştir. Bahçede yanında veziri, etrafında çeşitli hayvan ve yaratıklar ile tasvir edilmiştir. Bir kamp alanında simurg, ejderha, kuş, uzun boynuzlu keçi, koç, pars, fil, at, leylek, tilki ve çeşitli hayvanların yer aldığı minyatürde, Hz. Süleyman solunda bir melek figürü ve sağında oturan veziri ile sohbet içinde tasvir edilmiştir.

Minyatürün koyu fonu figürlerin canlı ve parlak renklerini ön plana çıkarmıştır. Minyatürde yeşil, mavi, kahverengi, sarı, krem rengi, altın, kırmızı, gri, siyah, mor, beyaz vb. renkler tercih edilmiştir.

Minyatürde yer alan iki tane simurg figürü tüm varlıkları ile neredeyse bütün gökyüzüne yayılmış ve havada kanatlarını açarak, gösterişli gövdesiyle uçarken tipik bir görünümde tasvir edilmiştir. Bulutlarla dolu gökyüzü ise simurgların uçuşması ile bir uyum sergilemektedir.

Kuşların dilini bilen $\mathrm{Hz}$. Süleyman'ın rüzgâr emrinde bulunuyordu. Bu yüzden istediği noktaya çok kısa zamanda gidip gelebilmekteydi. İnsanlardan, cinlerden ve kuşlardan oluşan kuvvetleri bulunmaktaydı (Aydemir; 1983:173). Kuşların Padişahı olan Hz. Süleyman'a bilgelik ve üstünlük verildiği, hayvanların, kuşların ve karıncaların dilinden anladığı söylenmektedir (Arpaguş; 2005:121-135). Bu sebepledir ki Hz. Süleyman'ı konu alan minyatürde leylek, baykuş vb. kuşların tasvirleri yer alırken $\mathrm{Hz}$. Süleyman'ın kuşlarla olan iletişiminin yanı sıra beşerî alemdeki tasavvurlarının, varlıklar ile iletişime geçebilme vasfı tasvirde yansıtılmıştır.

Minyatür tasarımının etrafına altın ile halkâr tezyinatı yapılmıştır. Altın ile renklendirilen halkâr tasarımında çift tahrir (negatif) boyama tekniği ile farklı hataî, gonca ve çeşitli yaprak motifleriyle tezyinat nihayetlendirilmiştir. 


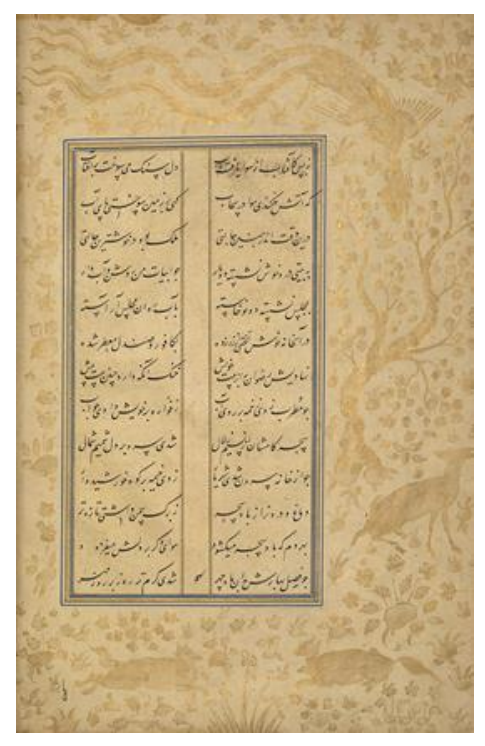

Görsel 3. Fıraknâme, Varak 10b, Fransa Milli Kütüphanesi, İslam koleksiyonu, Yazı alanı 103×190 mm, https://gallica.bnf.fr/ark:/12148/btv1b6001244v/f24.item.r=simurg.

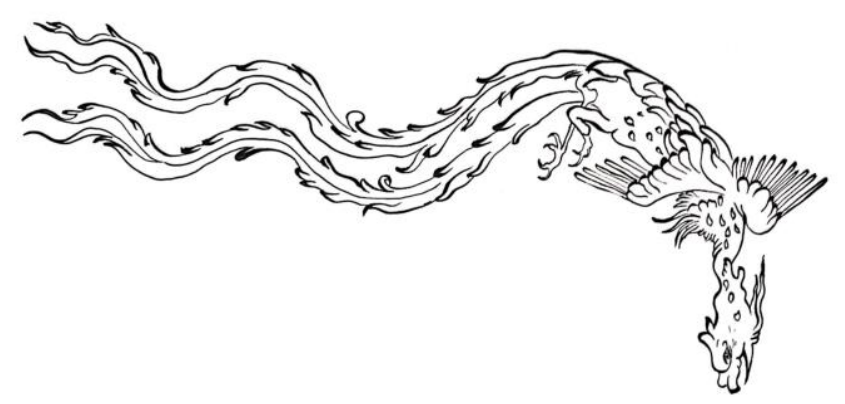

Çizim 2. Emlak, 2021, Varak 10b, Halkâr Tezyinatı, Simurg Figürü.

Eserin nohudi renkte olan $10 \mathrm{~b}$ varağında, 2 sütun 13 satırdan oluşan ve nestâlik yazı ile yazılan metin alanı bulunmaktadır. Yazı alanının dört tarafına halkâr tezyin edilmiştir. Tezyinatta Simurg figürü ön planda görkemli bir şekilde, gökte süzülürken tasvir edilmiştir. Halkâr tezyinatında hayvan tasvirlerinden Simurg'un yanı sıra tilki ve ceylan figürlerine yer verilmiştir. Bitkisel motiflerden ise penç, gonca ve küçük yapraklı yer bitkileri tezyin edilmiştir. Minyatür ve halkâr tezyinatında rastladığımız yapraklı ağaç tasvirine yer verilmiştir. 10b varağı tezyinatındaki kompozisyon düzenlemesinde figürler orantılı biçimde doluluk-boşluk oranı göz önünde bulundurularak yapılmıştır. Bitkisel motifler ile tezyinat tamamlanmıştır. Halkâr tezyinatında yer alan hayvan ve bitki motiflerinin altın ile bezenmesi tezyinatı müessir ve daha parlak kılmıştır. 


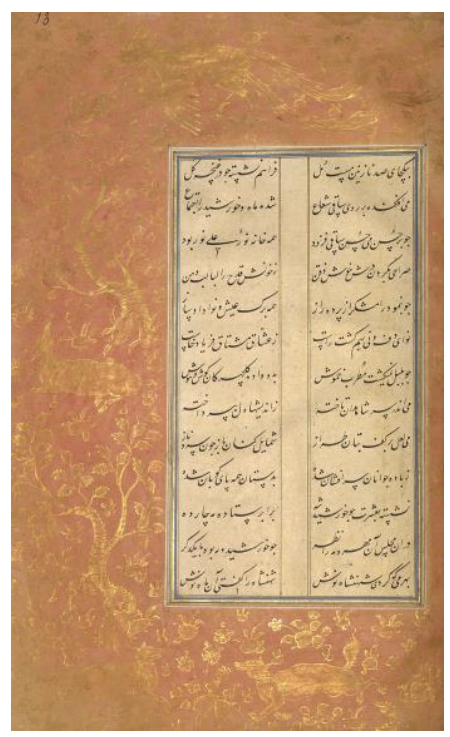

Görsel 4. Fıraknâme, Varak 13a, Fransa Milli Kütüphanesi, İslam koleksiyonu, Yazı alanı 103×190 mm, https://gallica.bnf.fr/ark:/12148/btv1b6001244v/f29.item.r=simurg.

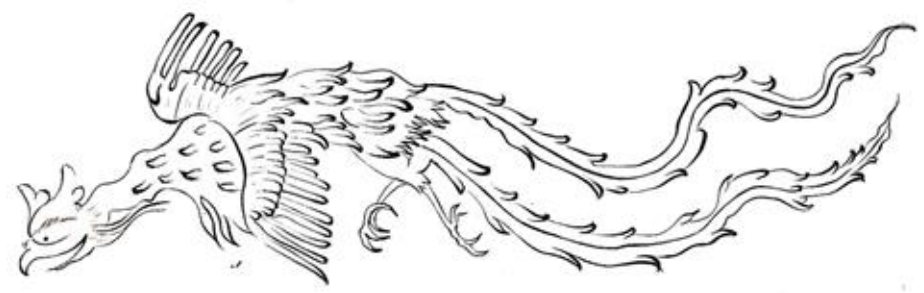

Çizim 3. Emlak, 2021, Varak 13a, Halkâr Tezyinatı, Simurg Figürü.

Eserin somon renkte olan 13a varağında, 2 sütun 13 satırdan oluşan ve nestalik yazı ile yazılan metin alanı bulunmaktadır. Yazı alanının dört tarafına halkâr tezyin edilmiştir. Simurg kuşu metnin üst kısmında gösterişli ve uçar bir şekilde tasvir edilmiştir. Halkâr tezyinatında simurg figürü ön planda gök yüzünde tasvir edilmiştir. Halkâr tezyinatında hayvan tasvirlerinden simurg, tilki ve ceylan figürlerine yer verilmiştir. Bitkisel motiflerden ise penç, gonca ve küçük yapraklı yer bitkileri yapılmıştır. Ayrıca küçük yapraklı, büyük ağaç tasvirleri kompozisyonda büyük ölçüde yer almıştır. 13a varağı tezyinatının kompozisyon düzenlemesinde figürlerin orantılı biçimde resmedildiği görülmektedir. Bitkisel motifler tamamlayıcı unsur olarak, dolulukboşluk oranına göre süslemeye yerleştirilmiştir. Altın ile renklendirilen halkâr bezemesinde, motifler daha parlak ve münevver bir görünüme sahiptir. 


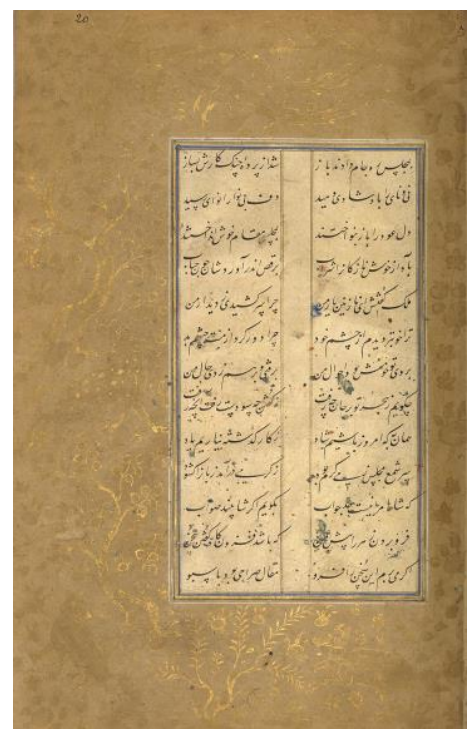

Görsel 5. Fıraknâme, Varak 20a, Fransa Milli Kütüphanesi, İslam koleksiyonu, Yazı alanı 103×190 mm https://gallica.bnf.fr/ark:/12148/btv1b6001244v/f43.item.r=simurg.

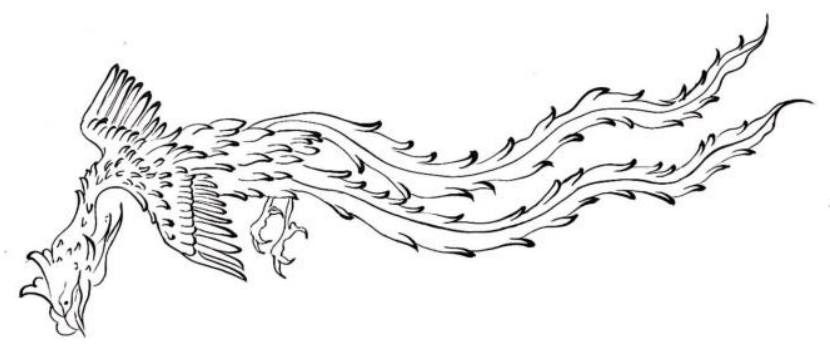

Çizim 4. Emlak, 2021, Varak 20a, Halkâr Tezyinatı, Simurg Figürü.

Eserin nohudi renkte olan 20a varağında 2 sütun 13 satırdan oluşan ve nestalik yazı ile yazılmış metin alanı bulunmaktadır. Yazı alanının dört tarafına halkâr tezyin edilmiştir. Simurg kuşu metnin üst kısmında gökyüzünde kanatları açık, uçar bir şekilde tasvir edilmiştir. Halkâr süslemesinde Simurg figürü ve ağaçlar ön planda tasvir edilmiştir. Halkâr tezyinatında hayvan tasvirlerinden Simurg'un yanı sıra tilki ve ceylan figürleri yer almıştır. Bitkisel motiflerden ise penç, gonca ve küçük yapraklı yer bitkileri bulunmaktadır. Eserin genelinde halkâr tezyinatında sıkça görülen yapraklı ağaç tasvirlerine bu sayfada da geniş ölçüde yer verilmiştir. 20a varağı kompozisyon düzenlemesinde ağaçlar ve hayvan figürleri halkâr tezyinatının büyük bir 
bölümüne işlenmiştir. Bezemede küçük taşların dibinden çıkan yer bitkileri ve penç motifleri ile süslenen dallar kompozisyon bütünlüğünde tamamlayıcı unsur olarak kullanılmıştır.

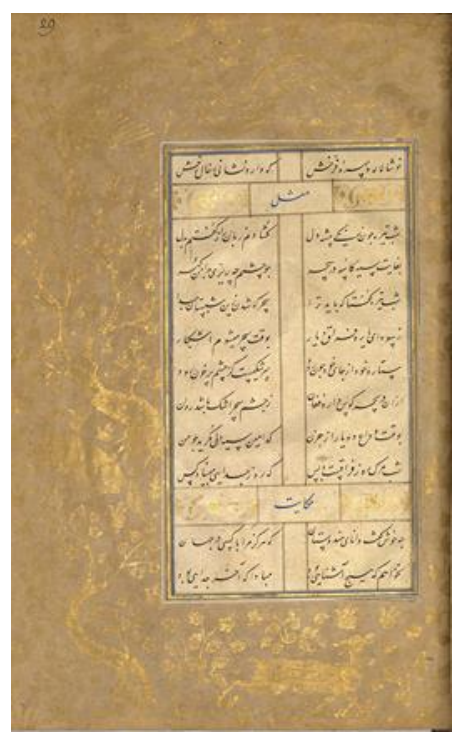

Görsel 6. Fıraknâme, Varak 29a, Fransa Milli Kütüphanesi, i̇slam koleksiyonu, Yazı alanı 103×190 mm https://gallica.bnf.fr/ark:/12148/btv1b6001244v/f61.item.r=simurg.

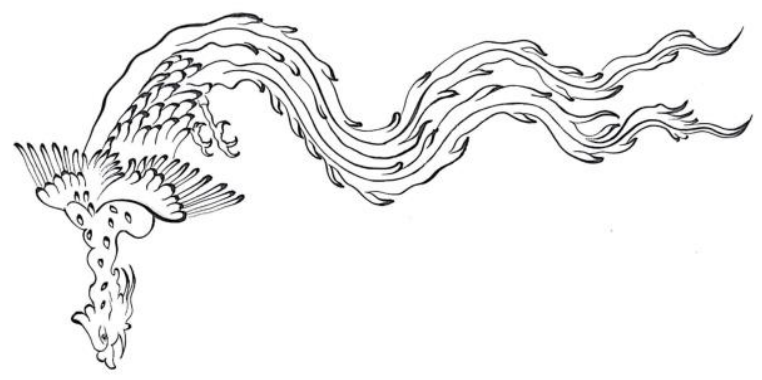

Çizim 5. Emlak, 2021, Varak 29a, Halkâr Tezyinatı, Simurg Figürü.

Eserin nohudi renkte olan 29a varağında 2 sütun 13 satırdan oluşan ve nestalik yazı ile yazılmış metin alanı bulunmaktadır. Metin alanının ikinci ve on birinci satırlarında mavi mürekkep ile başlık yazıları bulunmaktadır. Başlık yazılarının iki tarafına altın ile penç ve yaprak motifleriyle başlık tezhibi yapılmıştır. Metnin dört tarafına halkâr süslemesi yapılan sayfada, Simurg kuşu metnin üst kısmında diğer varaklarda tasvir edilen simurg figürlerinden daha büyük betimlenmiştir. Simurg figürü kanatları açık, uçar bir şekilde tasvir edilmiştir. Tezyinatta hayvan tasvirlerinden simurg, tilki ve benekli ceylan figürlerine yer verilmiştir. Bitkisel motiflerden ise 
penç, gonca ve küçük yapraklı yer bitkileri yapılmıştır. Ağaç tasvirleri ve hayvan figürleri bu varakta da ön planda yapılmıştır. 29a varağı tezyinatındaki kompozisyon düzenlemesinde figürler orantılı bir şekilde resmedilmiştir. Bitkisel motifler, hayvan figürlerinin etrafına dolulukboşluk oranına göre yerleştirilmiştir. Altın ile renklendirilen halkâri bezemedeki motifler daha ışıklı bir görünüme sahip olmuştur.

\section{Sonuç}

Simurg figürü bilhassa ilmi ve edebi eserlerin tezyinatında kullanılan, en ilginç mitolojik simgelerden biridir. İslamiyet'in kabulünden önceki bazı efsanevi kuşlarla ilişkilendirilen ya da benzer nitelikler taşıyan simurg figürü, farklı kültürlerde değişik isimlerle karşımıza çıkmaktadır. Simurg'un Fıraknâme'deki tasvirlerine bakıldığında geniş kanatlı, kuyruğu uzun ve kıvrımlı bir şekilde, keskin bir yüz ifadesi, sakal ve ibikli olarak karşımıza çıkmaktadır. Bu figür iyi ve kötü, yeniden doğuş gibi simgeler ile bütünleşmiş toplumdan topluma farklı efsaneler ile dile gelmiştir.

Eserin tezyinatının genel olarak değerlendirilmesinde, hayvan figürlerinden simurg, ejderha, uzun boynuzlu keçi, pars, tilki, keçi, ceylan vb. hayvanların tasvirlerini görmekteyiz. Eserde simurg figürüne cilt, minyatür ve halkâr tezyinatında rastlanmaktadır. Bağımsız bir şekilde tasvir edilen simurg kuşları eserin cildinin alt ve üst kabında, 2a varağında Süleyman peygamberi konu alan minyatürde ve 10b, 13a, 20a, 29a varağındaki halkâr tezyinatında yer almaktadır. Halkâr tezyinatındaki simurg tasvirleri iri bir şekilde benzer formlarda betimlenmiştir. Eserin cildindeki simurg figürü bir ejderha ile dövüş içerisinde tasvir edilmiştir. Simurg figürünün mitolojik anlamları itibari ile bu figüre atfedilen güç unsuru savaş sahnelerinde sıkça yer verilmesine sebep olmuştur.

Simurg figürünün işlendiği 2a varağındaki Hz. Süleyman'ın hükümdarlığını temsilen yapılmış ve iyilik timsali olarak işlenen sahnede $\mathrm{Hz}$. Süleyman tahta oturmuş, etrafında da her türden hayvan resmedilerek onun hem insanlar hem de hayvanlar aleminin hükümdarı olduğu vurgulamaktadır.

Eserde halkâr tezyinatında yer alan Simurg figürleri gösterişli ve gökyüzünde süzülür şekilde betimlenmiştir. Simurg figürü tasvirinin olduğu her varakta figür ön planda yapılmıştır. 
Bilhassa halkâr tasarımlarının 4/1'ini kapsayacak şekilde hacimli bir şekilde sayfanın üst kısmına tasvir edilmiştir.

Eserin kompozisyon özelliklerinde sayfanın büyük bir kısmına bezeme yapıldığı ve kullanılan motiflerde bir bütünlük olduğu gözlemlenmiştir. Her sayfanın tasarımında cetveller çekilerek yazı alanı çerçeve içine alınmış ve dört tarafına tezyinat yapılmıştır. Eserin cilt, minyatür ve halkâr tasvirlerinde kullanılan hayvan figürlerinde bir üslûp birliği olduğu anlaşılmaktadır. Bitkisel motiflerde de aynı bütünlük görülmektedir. Kullanılan renklerde ise minyatür tasvirindeki koyu ve parlak renkler sahneyi canlı kılmıştır. Eserin cilt ve halkâr renklendirmelerinde kullanılan yoğun altın, tezyinatı parlak ve zengin kılmıştır.

Fıraknâme eserinde metin içeriğine özgü bir resimleme gerçekleşmiş olabileceği gibi eserin içeriğinden bağımsız bir şekilde yer alan halkâr tasarımlarında da simurg figürünü görmekteyiz. Ancak Selman Saveci'nin ele aldığı konularda tabiat olaylarını gözlemlediği ve metinlerine yansıttığı vurgulanmaktadır. Mevsimin gelişi ile doğada oluşan güzellikleri farklı benzetmeler ile metne yansıtan şairin dizelerine yönelik sanatçının bir tasavvur geliştirilmiş olabileceği ve halkâr tezyinatında doğa tasvirlerine yönelik bir tezyinat husul bulduğu düşünülmektedir.

Çalışma konumuzun sonucunda Fıraknâme tezyinatının hayvan üslubuna dair örnek bir nüsha olmanın yanı sıra yazma eserlerde hayvan figürlerinin kullanıldığı alanlara ilişkin bilgi verdiği görülmektedir. Simurg figürünün mitleri ve söylencelerine dair bilgi veren çalışmamızda Fıraknâmenin hem ihtiva ettiği edebi niteliği bakımından hem de sanat açısından mühim bir nüsha olduğu anlaşılmaktadır. 


\section{Kaynakça}

And, M. (2008). Minyatürlerle Osmanlı-Islam Mitologyası, 3. Baskı, İstanbul: Yapı Kredi Yayınları.

Arpaguş, S. (2005). Tasavvufta 'Mantıku't-tayr' Mevlânâ'da Hz. Süleyman ve Kuşdili Tasavvuru, Marmara Üniversitesi Ilahiyat Fakültesi Dergisi, Sayı 29, s.121-135.

Aydemir A. (1983). "Hz. Süleyman (A.S.)”, Dokuz Eylül Üniversitesi Ilahiyat Fakültesi Dergisi I, İzmir, s.173.

Batislam H. Dilek, (2002). "Divan Şiirinin Mitolojik Kuşları: Hümâ, Anka ve Simurg” Türk Kültürü incelemeleri Dergisi, İstanbul, Sayı 7, s.185-208.

Begiç, H. N. (2017). Türk Keçecilik Sanatı, Atatürk Kültür Merkezi Yayınları. Ankara: Etkileşim Basın Yayın.

Bilgehan, G. (2003). Pembe Köşkten Masallar, Ankara: Bilgi Yayınevi.

Çoruhlu, Y. (2002). Türk Mitolojisinin Ana Hatları, I. Baskı, Kabalcı Yayıncılık: İstanbul.

Çoruhlu, Y. (2014). Türk Sanatında Hayvan Sembolizmi, I. Baskı, Konya: Kömen Yayınları.

Çağrıcı M. (1997). "Hanzale b. Safvaân er Ressî” İslâm Ansiklopedisi, İstanbul: Türkiye Diyanet Vakfı Yayınları, Cilt:16, s.53

Derman, Ç. "Halkârî", İslâm Ansiklopedisi, İstanbul: Türkiye Diyanet Vakfı Yayınları, Cilt 15, s.365-367.

Dieji, A. (2007). Iran Minyatüründe Savaş Sahneleri, (Yayımlanmamış Doktora Tezi) İstanbul Üniversitesi, Sosyal Bilimler Enstitüsü, İstanbul.

Erdem, S. (1991). “Anka”, İslâm Ansiklopedisi, İstanbul: Türkiye Diyanet Vakfı Yayınları, Cilt 3, s.198-200.

Emini N. G. (1998) Selman-ı Saveci ve Cemşid ü Hurşid Mesnevisi, Selçuk Üniversitesi FenEdebiyat Fakültesi Edebiyat Dergisi, Sayı 12, s.71-91.

Eliade, M. (2001). Mitlerin Özellikleri, çev. Sema Rıfat, İstanbul: Om Yayınevi.

Hınnels, John R. (1985). Persian Mythology, London.

Karakuş, G. (2020). Simurg Söyleni Üzerine Görsel Anlatılar, Yayımlanmamış Doktora Tezi, Ankara: Hacettepe Üniversitesi, Güzel Sanatlar Enstitüsü, Resim Ana Sanat Dalı. 
Karasar, N. (2008). Bilimsel Araştırma Yöntemi, 18. Baskı, Ankara: Nobel Yayın Dağıtım.

Karaismailoğlu, A. (2009). "Selmân-ı Sâvecî", İslâm Ansiklopedisi, İstanbul: Türkiye Diyanet Vakfı Yayınları, Cilt 36, s.446-447.

Mehran, S. (2017). Simurg, Yayımlanmamış Yüksek Lisans Tezi, Erzurum: Atatürk Üniversitesi, Sosyal Bilimler Enstitüsü, Fars Dili ve Edebiyatı Ana Bilim Dalı.

Pala, ì. (1991). "Anka", İslâm Ansiklopedisi, İstanbul: Türkiye Diyanet Vakfı Yayınları, Cilt 3, s.201.

Purnamdariyan, T. (1955). Didar ba Simurg, Intisarat-i Pejuhesgâhi Ulum-i Insanı ve MutâliatFerhenngi.

Tavukçu, O. K. (2004). Türk Edebiyatında Firâk-nâme Adlı Eserler, Türk Kültürü Incelemeleri Dergisi, İstanbul, Sayı 10, s.89-122.

Tavukçu, O. K. (2007). Türkiye Araştırmaları Literatür Dergisi, Cilt 5, Sayı 10, s.197-220.

Yaylalı, Y. (2017). Selmân-ı Sâvecî'nin Firâknâme'sinde Mevsim Tasvirleri, Türkiyat Araştırmaları Enstitüsü Dergisi, Erzurum, Sayı 58, s.203-219.

Yıldırım, N. (2006). Fars mitolojisi sözlüğü, İstanbul: Kabalcı Yayınevi.

Ziyâyi, M. "Firâk-nâme”, Dâniş-nâme-i Edeb-i Farsi, Editör: Hasan-i Enûşe, Tahran.

\section{Internet Kaynakları}

Duymaz, A. (1998). Anadolu ve Balkan Türklerinin Halk Anlatmalarında Mitolojik Bir Kuş: Zümrüdü Anka, Balıkesir Üniversitesi Sosyal Bilimler Enstitüsü Dergisi (Cilt: 1 Sayı: 1), s.91-97. http://sbe.balikesir.edu.tr/dergi/edergi/c1s2/makale/c1s2m6.pdf , Erişim tarihi: 21.07.2020.

Güler, Z. (2014), "Şeyh Galip Divanında Anka-Simurg Sembolü", International Journal of Language,Academy, https://earsiv.kmu.edu.tr/xmlui/bitstream/handle/11492/791/\%c5\%9eeyh \%20Galib\%20Divan\%c4\%b1nda\%20AnkaSimurg\%20Sembol\%c3\%bc.pdf?sequence=1\&isAllowe $\mathrm{d}=\mathrm{y}$,Erişim tarihi: 23.07.2020.

\section{Görsel Kaynaklar}

Görsel 1. Fıraknâme'nin eserinin ön ve arka cildi, Fransa Milli Kütüphanesi'nin, İslam koleksiyonu, https://gallica.bnf.fr/ark:/12148/btv1b6001244v/f1.item.r=simurg.

Görsel 2. Firaknâme, Varak 2a Hz. Süleyman Peygamber, Fransa Milli Kütüphanesi'nin, İslam koleksiyonu, https://gallica.bnf.fr/ark:/12148/btv1b6001244v/f6.item.r=simurg. 
Görsel 3. Firaknâme, Varak 10b, Fransa Milli Kütüphanesi'nin, issam koleksiyonu, https://gallica.bnf.fr/ark:/12148/btv1b6001244v/f24.item.r=simurg.

Görsel 4. Fıraknâme, Varak 13a, Fransa Milli Kütüphanesi'nin, islam koleksiyonu, https://gallica.bnf.fr/ark:/12148/btv1b6001244v/f29.item.r=simurg.

Görsel 5. Fıraknâme, Varak 20a, Fransa Milli Kütüphanesi'nin, islam koleksiyonu, https://gallica.bnf.fr/ark:/12148/btv1b6001244v/f43.item.r=simurg.

Görsel 6. Fıraknâme, Varak 29a, Fransa Milli Kütüphanesi'nin, islam koleksiyonu, https://gallica.bnf.fr/ark:/12148/btv1b6001244v/f61.item.r=simurg. 